\title{
Evaluation of Social Skills in Older Adults and Adults
}

\author{
Jucelaine Bier Di Domenico-Grazziotin ${ }^{1}$ \\ Silvana Alba Scortegagna \\ Graduate Program in Human Aging of the Universidade de Passo Fundo, \\ Passo Fundo, RS, Brazil
}

\begin{abstract}
Social competence comprises one of the indispensable conditions for mental health. The aim of this study was to evaluate the Social Skills (SS) repertoire in older adults and adults to verify whether older adults, especially those of the older age groups, present a less developed SS repertoire. Participants of this study were 135 healthy subjects aged 18 to 83 years, divided into two groups: one group (Older Adults Group [OAG]) consisting of 61 older adults, and the other group (Adults Group [AG]) consisting of 74 adults. The instruments used were a sociodemographic and health characterization questionnaire, the Social Skills Inventory-Del Prette (SSI) for adults and the SSI adapted for older adults. There were significant and negative correlations between the age of the participants and the overall SS score GSSI (Overall Score Social Skills Inventory; $r=.20)$, in the positive affect F2 $(r=.249)$, in the conversation and social confidence F3 $(r=.259)$ and in self-control of aggressiveness F5 $(r=.490)$ factors. The OAG presented more restricted social interactions and a less developed SS repertoire, compared to the AG. The development of public policies that valorize SS to help sustain the well-being of older adults is a necessity in the Brazilian socioeconomic and cultural context.
\end{abstract}

Keywords: Psychological assessment, human aging, interpersonal relationship, culture.

\section{Avaliação das Habilidades Sociais em Adultos Idosos e Adultos}

\section{Resumo}

A competência social consiste em uma das condições indispensáveis para a atribuição de saúde mental. Este estudo objetivou avaliar o repertório de Habilidades Sociais (HS) em adultos idosos e adultos e verificar se adultos idosos, especialmente as faixas etárias mais velhas, apresentavam um repertório menos desenvolvido em HS. Participaram desse estudo 135 indivíduos saudáveis com idades entre 18 e 83 anos, distribuídos em dois grupos: um grupo de adultos idosos com 61 participantes, e outro grupo de adultos, com 74 indivíduos. Os instrumentos utilizados foram um protocolo de caracterização sociodemográfica e de saúde, o Inventário de Habilidades Sociais-Del Prette (IHS) para adultos e o IHS adaptado para idosos. Houve correlações significativas e negativas entre a idade avançada dos participantes e as HS no escore geral GIHS (Escore Geral do Inventario de Habilidades Sociais; $r=0,20$ ), no afeto positivo F2 $(r=0,249)$, na conversação e desenvoltura social F3 $(r=0,259)$ e, no autocontrole da agressividade F5 $(r=0,490)$. Os adultos idosos, apresentaram interações sociais mais restritas e um repertório nas HS menos desenvolvido, em comparação aos adultos. O desenvolvimento de políticas públicas que valorizem as HS para auxiliar a sustentar o bem-estar na idade adulta mais velha é uma necessidade do contexto socioeconômico e cultural brasileiro.

Palavras-chave: Avaliação psicológica, envelhecimento humano, relacionamento interpessoal, cultura.

1 Mailing adress: Universidade de Passo Fundo, Programa de Pós-Graduação em Envelhecimento Humano, BR 285 - Cx. Postal 611, Bairro São José, Passo Fundo, RS, Brazil 99052-900. E-mail:jucelainegraz@terra.com. br and silvanalba@upf.br 


\section{Evaluación de las Habilidades Sociales en los Adultos Mayores y los Adultos}

\section{Resumen}

La competencia social consiste en dar condiciones indispensables para la atribución de la salud mental. El estudio objetivó evaluar el repertorio de Habilidades Sociales (HS) en adultos mayores y adultos y verificar si los ancianos, de manera especial los grupos de edades más avanzadas, presentaban un repertorio menos desarrollado en HS. Participaron 135 personas sanas, con edades entre 18 y 83 años, seleccionados en dos grupos: un grupo de 61 adultos mayores, y otro grupo de 74 personas adultos. Los instrumentos utilizados fueron preguntas de caracterización socio demográfica y de salud, el Inventario de Habilidades Sociales-Del Prette (IHS) para adultos y, para los mayores, ha sido adaptado el IHS. Hubo correlación significativa negativa entre la edad avanzada de los participantes y las HS en la puntuación general GIHS (Escore Geral do Inventario de Habilidades Sociais; $r=.20$ ), en el afecto positivo F2 $(r=.249)$, en la conversación y desenvoltura sociales F3 ( $r=.259)$, y en el autocontrol de la agresividad F5 $(r=.490)$. Los adultos mayores presentaron interacciones sociales más restrictas y un repertorio en las HS menos desarrollado, en comparación a los adultos. El desarrollo de políticas públicas que valoren las HS para auxiliar y para mantener el bienestar en la edad adulta mayor es una necesidad del contexto socioeconómico y cultural brasileño.

Palabras clave: Evaluación psicológica, envejecimiento humano, relación interpersonal, cultura.

Worldwide a process of demographic transition is taking place that is leading to a predominance of older populations. The proportion of people aged 60 years and over should double and reach two billion by 2050 (United Nations, 2012). In Brazil, estimates project that the number of older adults will exceed 30 million by 2025 (Instituto Brasileiro de Geografia e Estatística [IBGE], 2010).

The sharp increase in older adults has consequences for society with regard to health, education, labor, services, and research development (American Psychological Association, 2014). Thus, it is necessary to seek the determinants of the health and disease conditions that affect the aging process and old age, especially in emerging countries, such as Brazil, where studies are incipient (BastosFormighieri \& Pasian, 2012). Among these factors are the Social Skills (SS), which cover the quality of interpersonal relationships, with regard to communication, civility, assertiveness, empathy, work and the expression of positive feelings (Del Prette \& Del Prette, 2011, 2013).

Social skills are classes of behavior that exist in the repertoire of the individual and con- tribute to socially responsible behavior. Such behavior implies performing functions expected by society, which can be: leadership and the coordination of groups, in order to manage stress and interpersonal, intrapersonal and intergroup conflicts (Del Prette \& Del Prette, 2001, 2013).

A well developed SS repertoire relates to greater personal and professional satisfaction and, consequently, contributes to promoting quality of life and mental health (Caballo, 2008; Del Prette \& Del Prette, 2005, 2013; Del Prette, Falcone, \& Murta, 2013). The disorders and psychological problems associated with deficits in SS include stress, loneliness, depression, increased risk of suicide, anxiety, and marital conflict (Angélico, Crippa, \& Loureiro, 2012; Carneiro, Falcone, Clark, Del Prette, \& Del Prette, 2007; Del Prette et al., 2013; Pinto \& Barham, 2014; Schlösser, Rosa, \& More, 2014). The presence of these problems can be influenced by the kinds of social interactions that people establish throughout life, as well as being due to personal and contextual factors (Del Prette \& Del Prette, 2005, 2011).

Regarding the contextual issues, SS can be learned and culturally determined, thus 
highlighting the importance of the opportunities arising from the environmental and social context (Del Prette \& Del Prette, 2005). The environment does or does not reinforce social behavior and enable the learning of new skills through observation and interaction. Environmental elements include the age and stage of development, gender, education, and the family, cultural, socioeconomic and occupational situations.

Interactions and social activities can enhance the expansion of social support networks and help in coping with various interpersonal demands, as well as contributing to personal efficacy, for the formation of a positive identity and good self-esteem. The development of assertiveness, for example, which assumes the expression of rights, thoughts, feelings and beliefs in a way that does not violate the rights of others, can be extremely relevant (Braz, Del Prette, \& Del Prette, 2011).

While responses to aging occur differently for each individual, little valorization of older adults and the positive aspects, such as maturity and wisdom, in Western culture (Baltes \& Baltes, 1990; Garcia-Santos, Almeida, \& Werlang, 2012), together with the increase of the negative aspects, such as losses due to senescence, may lead to smaller investments being made in interpersonal, social-affective and productive relationships (McAdams \& Olson, 2010; Neri \& Vieira, 2013; O’Brien, Konrath, Gruhn, \& Hagen, 2013). Adults 80 years and over especially tend to present more physical limitations and restrictions in social engagement (Neri \& Vieira, 2013). The author points out that the involvement in social activities are beneficial for cognition, health, longevity and functionality and favor feeling useful, the sense of belonging and exchanges of help, which should be encouraged.

It is in this context that the field of SS is included, as behavior classes that contribute to health promotion, to overcome the difficulties in clinical and educational intervention and in the prevention of personality disorders (Angélico et al., 2012; Braz, Cômodo, Del Prette, Del Prette, $\&$ Fontaine, 2013; Braz et al., 2011; Carneiro et al., 2007; Del Prette et al., 2013; Di DomenicoGrazziotin \& Scortegagna, 2012, 2013; Feitosa, Del Prette, \& Del Prette, 2012; Guilland \& Monteiro, 2010; Neri \& Vieira, 2013; Pinto \& Barham, 2014). The correlation between SS and psychological well-being, suggesting that the higher the SS index, the better the health condition and lower the probability of satisfying the screening criteria of indicators for the disease, was identified in studies with adults (Angélico et al., 2012; Guilland \& Monteiro, 2010; Pinto \& Barham, 2014).

Other studies with adolescents and adults also showed the association between SS and interpersonal relationships in the school and work environments, reaffirming that individuals with higher scores in SS interact more and present greater academic achievement (Di DomenicoGrazziotin \& Scortegagna, 2012, 2013; Feitosa et al., 2012). Although studies are scarce with the older adult population, the SS have been related to quality of life, social support and depression, indicating that deficiencies in these skills can be a vulnerability factor for a low quality of life (Carneiro \& Falcone, 2013; Carneiro et al., 2007).

In view of these findings, some researchers have shown the ability to intervene to develop the SS repertoire. Braz et al., (2011) evaluated the effects of a training program for assertive SS with 15 older adults aged 60 and over, distributed in two groups. The first, an experimental group, consisted of seven women and one man, mean age 67.5 years, and the second, a control group, of six women and one man, mean age 65.5. The authors used the Social Skills Inventory Older Adults (SSIOA-Del Prette), with the adaptation of certain phrases from the Social Skills Inventory-Del Prette (SSI-Del Prette) for individuals 60 years of age and over (Carneiro et al., 2007). The results indicated significant differences in the pretest and posttest, with an increase in overall SS score in the latter.

Subsequently, Braz et al., (2013) conducted two studies in order to investigate the correlation between the SS repertoire among older adult parents and adult children, and the influence of the quality of the relationship between them 
on the repertoire of these skills. The first study evaluated 142 dyads, adult parents and adolescent children. The second study investigated the relationship between 77 older adult parents and 107 adult children. The instruments used were: The Social Skills Inventory Adolescents (SSIADel Prette), the SSI-Del Prette and the SSIOA adapted for older adults (Carneiro et al., 2007). Results showed similarities for 29 of the 38 SS evaluated between the dyads and also evidence of intergenerational transmission of several SS classes, especially between mothers and adolescent children.

In the quest to map other variables that may be involved in the development of SS, Neri and Vieira (2013) analyzed the relationship between involvement and social support in older adults, considering the age, gender, education and location of residence. A total of 1,451 older adults without cognitive impairment suggestive of dementia participated in the study. The instrument used was the Mini Mental State Exam (MMSE), a questionnaire covering the performance of advanced activities of daily living and perceived social support. Among the results, social involvement was higher among the women, the younger subjects between 65-74 years of age, those with higher levels of education and those living in economically more developed locations. Negative correlations between social involvement and age were observed.

Considering that SS may be associated with mental health, good interpersonal relationships and quality of life (Angélico et al., 2012; Braz et al., 2011; Carneiro \& Falcone, 2013; Carneiro et al., 2007; Guilland \& Monteiro, 2010; Neri \& Vieira, 2013; Pinto \& Barham, 2014), the aim of this study was to evaluate the SS repertoire in older adults and younger adults and to verify whether older adults, especially those of older age groups, present a less developed SS repertoire when compared with the younger adults.

If the older adults present decline and limitations in investments of interpersonal and social relationships (Braz et al., 2011; McAdams \& Olson, 2010; Neri \& Vieira, 2013; O’Brien et al., 2013), the hypothesis arises that advancing age, combined with socio-demographic and cultural conditions, may cause a significant reduction in the scores of the F1 (Coping and selfassertion with risk), F2 (Self-assertion in the expression of positive affect), F3 (Conversation and social confidence) F4 (Self-exposure to unknown people or new situations) and F5 (Selfcontrol of aggressiveness in aversive situations) factors and in the overall score - GSSI (Overall Score Social Skills Inventory; Del Prette \& Del Prette, 2005).

\section{Method}

\section{Participants}

Participants of this study were 135 people aged 18 to 83 years, non-randomly selected and distributed into two groups. The first group (Older Adults Group [OAG]) consisted of 61 older adults, aged 60 and over ( $45 \%$ of the sample), with mean age of 68.75 years $(S D=6.36)$, including 43 women and 18 men, with mean schooling of 7 years $(S D=2.33)$ and mean remuneration of 1.7 minimum wages $(S D=.67)$, married $(71 \%)$ coming from community centers. The second group consisted of 74 adults (Adults Group [AG]), less than 60 years of age ( $55 \%$ of the sample), with mean age of 37 years $(S D=14.3)$, including 46 women and 28 men, with mean schooling of 10 years $(S D=2.03)$ and mean remuneration of 1.8 minimum wages $(S D=.53)$, married (53\%), from commercial establishments, working with customer service activities.

Regarding the inclusion and exclusion criteria for the OAG, those aged 60 years and over, who participated in activities in community groups were eligible for inclusion in the study. For the AG, those between 18 and 59 years of age, who worked directly with customer service activities in commercial establishments were considered. For both groups, participation in the study was conditional on not presenting: (a) history of psychiatric treatment and/or conditions affecting the ability to perform cognitive or physical activities; (b) history of any important loss which caused suffering, within the previous six months. These data were obtained through the application of the sociodemographic and health characterization questionnaire. 


\section{Instruments}

Sociodemographic and Health Characterization Questionnaire. Used to verify the inclusion or exclusion criteria, and characterize the sample. The instrument consists of 12 closed questions regarding age, gender, marital status, occupation, educational level, and socioeconomic and health conditions (presence of diseases, medical/psychiatric treatment, and losses in the previous six months).

Social Skills Inventory (SSI; Del Prette \& Del Prette, 2001). This instrument aims to evaluate the social skills usually required in everyday situations (work, family, friends) through 38 items that describe an interpersonal relationship and a possible outcome. In the response to each item, the respondent must estimate how often he/she reacts to a specific situation, on a 5 point Likert scale, ranging from 0 (never or rarely) to 4 (always or almost always), with a total score between 0 and 152. It presents the following factor structure: (a) Factor 1 (F1): Coping and self-assertion with risk (consisting of items 1, 5, 7, 11, 12, 14, 15, 16, 20, 21, 29); (b) Factor 2 (F2): Self-assertion in the expression of positive affect (items 3, 6, 8, 10, 28, 30, 35); (c) Factor 3 (F3): Conversation and social confidence (items 13, 17, 19, 22, 24, 36, 37); (d) Factor 4 (F4): Self-exposure to unknown people and new situations (items 9, 14, 23, 26); (e) Factor 5 (F5): Self-control of aggressiveness in aversive situations (items 18, 31, 38).

In interpreting the results, the lower the percentile, the more the individual tends to present a deficit in their SS repertoire and the higher the percentile, the better their SS repertoire. Values 0 to 20 are considered low (L) and indicate deficits in SS. Scores between 25 and 45 are considered low medium (LM), and those close to 50 , medium $(\mathrm{M})$, analyzed as a good repertoire. Values 55 to 75 are evaluated as high medium (HM), interpreted as an elaborate repertoire, and scores of 80 and above considered high $(\mathrm{H})$, corresponding to a very elaborate repertoire.

In the analysis of the psychometric properties, the SSI-Del Prete presented a pattern of reliability and satisfactory internal consistency with a Cronbach's alpha of .75; test-retest stability
( $r=.90 ; p=.001)$ and concurrent validity with the Rathus Inventory $(r=.79 ; p=.01)$ (Bandeira, Costa, Del Prette, Del Prette, \& Gerk-Carneiro, 2000). As this instrument was validated for the university population from 18 to 25 years of age, for this study, the adaptation was performed of the questions numbered: $2 ; 5 ; 8 ; 10 ; 11 ; 13 ; 14$; $15 ; 17 ; 18 ; 22 ; 29 ; 34$ and 38 , for the 60 years and over age group (Carneiro et al., 2007). Thus, the SS inventory for older adults, consists of a version of the SS Inventory (SSI-Del Prette), with the psychometric properties being the same as those established in the original version (Del Prette \& Del Prette, 2001). The adjustments did not alter the structure of the questions, however, some terms were replaced to adapt to the reality of the older adult population, e.g.: question 2 The terms "parent" and "older siblings" were replaced by "children", "sibling" and "nephews/ nieces"; in question 5 the term "relative" was added; in question 8 "Even with people known from school or work" was changed to "even with acquaintances" (Carneiro et al., 2007).

\section{Procedures}

With the possession of the letter of authorization of the institutions, and approval of the study from the Research Ethics Committee of the Universidade de Passo Fundo (UPF), authorization number $076 / 2009$, the data collection began. The OAG participants were recruited at a community center with approximately 250 members. After presentation of the aims and procedures of the study to the participants, during the performance of community groups, those that expressed interest in joining the study were referred by the coordinators of the groups.

The AG participants were recruited from two commercial establishments, with approximately 130 employees, located in the city center. After presentation of the aims and procedures of the study to the employees who directly performed customer service functions, those that expressed interest in taking part in the study were referred by the manager of the commercial sector.

The participants of this study signed an Informed Consent (IC) form and answered the instruments, after a brief period to establish rap- 
port, individually, in a session of approximately 35-minutes duration on the premises of the institutions. The application of the instruments was conducted by the main author of the study, and by an appropriately trained student of the Specialization Course in Health Psychology of the UPF. First the sociodemographic and health characterization questionnaire was applied (exclusion criteria) and then the SSI-Del Prette for the AG and the adapted SSI for the OAG. For the OAG the administration was carried out with assistance, upon request, and for the AG, the instrument was self-administered.

The data were generated according to the SSI-Del Prette manual adapted for the older adult population. For the data analysis, the sta- tistical program SPSS, version 18.0 was used. Upon completion of the descriptive statistics the association between the scores of the instrument and the age of the participants was calculated through Pearson's correlation coefficients $(p \leq .05)$. The parametric test was chosen because the variables followed a normal distribution, a result obtained after applying the KolmogorovSmirnov test.

\section{Results}

In the description of the results, the descriptive statistics of the SSI-Del Prette are presented first. Next, Pearson's correlation between the SSI-Del Prette and age of the participants are shown.

\section{Table 1}

Mean and Standard Deviation of the SSI-Del Prette Scores of the Participants

\begin{tabular}{lcccc} 
& \multicolumn{2}{c}{$\begin{array}{c}\text { Older Adults } \\
60 \text { years and over } \\
N=61\end{array}$} & $\begin{array}{c}\text { Adults } \\
\text { Less than } 60 \text { years } \\
N=74\end{array}$ \\
\hline SSI & Mean $S D$ & Mean $S D$ \\
\hline GSSI & 41.38 & 31.11 & 51.82 & 30.11 \\
F1SSI & 54.52 & 32.68 & 46.50 & 31.49 \\
F2SSI & 47.07 & 32.49 & 60.84 & 30.16 \\
F3SSI & 41.20 & 36.10 & 55.69 & 33.99 \\
F4SSI & 36.04 & 23.11 & 43.93 & 25.26 \\
F5SSI & 34.85 & 19.50 & 57.04 & 24.23 \\
\hline
\end{tabular}

Note. GSSI = Overall Score Social Skills Inventory. In the mean, the values obtained in percentile of the computerized SSI-Del Prette are shown.

The data presented in Table 1 show that the participants of the OAG produced results slightly below the medium range in the overall social skills score and in the conversation and social confidence (F3), self-exposure to unknown people or new situations (F4) and selfcontrol of aggressiveness in aversive conditions (F5) factors. However, in the coping and selfassertion with risk (F1) and self-assertion in the expression of positive affect (F2) factors, the results were within the medium range.

The AG presented results within the medium range for the overall score of social skills
(GSSI) and for the coping and self-assertion with risk $(\mathrm{F} 1)$ and conversation and social confidence (F3) factors. They obtained prominence in the self-assertion in the expression of positive affect (F2) and self-control of aggressiveness in aversive situations (F5) factors, with scores above the medium range. However, it can be seen that in the self-exposure to unknown people and new situations (F4) factor, the scores were below the medium range, suggesting difficulties in this area. These results suggest that the SS in general and in the corresponding factors, were less developed in the OAG when compared to the skills 
Table 2

Correlations of SSI-Del Prette with the Ages of the Participants

\begin{tabular}{ccccccc}
\hline Age & GSSI & F1SSI & F2SSI & F3SSI & F4SSI & F5SSI \\
\hline Pearson's correlation & $-.201^{*}$ & .134 & $-.249^{* *}$ & $-.259^{* *}$ & $-.186^{*}$ & $.490^{* *}$ \\
Sig. (2-tailed) & .020 & .122 & .004 & .002 & .031 & .000 \\
\hline
\end{tabular}

$*$ Significant $p \leq .05 ; * *$ significant $p \leq .01$.

of the AG. Next, results of the Pearson's correlation analysis between the SSI-Del Prette and age of the participants are shown.

In Table 2, statistically significant, negative and low correlations can be observed between older age and the GSSI, self-assertion in the expression of positive affect (F2), and conversation and social confidence (F3). It shows a significant, moderate and negative correlation between older age and self-control of aggressiveness in aversive situations (F5). These data corroborate the findings in Table 1 and are discussed below.

\section{Discussion}

The aim of this study was to evaluate the SS repertoire in adults and older adults and to verify whether older adults, especially those of the older age groups, present a less developed SS repertoire when compared with the other adults. Among the results of the GSSI overall score it was found that the OAG presented a repertoire within the low medium range, while the AG remained within the medium range, and that there was a significant, low and negative correlation of GSSI with age ( $r=.201)$. These data demonstrate the possibility of SS in general, that depict the capacity for empathy and emotional expressiveness and can promote interpersonal relationships and well-being in different contexts (Angélico et al., 2012; Del Prette \& Del Prette, 2005, 2011; Di Domenico-Grazziotin \& Scortegagna, 2012, 2013; Feitosa et al., 2012; Guilland \& Monteiro, 2010), being developed less as age advances. These findings confirm the initial hypothesis of this study, and corroborate previous studies which claim that, although aging occurs heterogeneously, in older adults there may be less in- vestment in interpersonal, social and productive relations (McAdams \& Olson, 2010; O'Brien et al., 2013). This may be due, for example, to the conflicts of the aging phase (Braz et al., 2011; Del Prette \& Del Prette, 2011). It is common in the more advanced ages that the older adults experience situations that require coping with the loss of close people, adjusting the socioeconomic conditions and the worsening of the social status, especially in the Western cultures (Neri \& Vieira, 2013).

In F2 (self-assertion in the expression of positive affect) involving affirmation of selfesteem, making friends, praising people and acknowledging compliments (Del Prette \& Del Prette, 2005), it appears that the older adults of this study presented a score within the medium range. The significant, negative and low correlation $(r=.249)$ indicates a tendency for selfassertion in the expression of positive affect (F2) to be developed less as age advances. This finding also confirms the initial hypothesis of this study, that this capacity decreases in older adults with more advanced ages, and corroborates other studies (McAdams \& Olson, 2010; Neri \& Vieira, 2013; O’Brien et al., 2013).

It is important to consider that the reduction in the affective field does not only result from increased age, but from a multifactorial context (health, economic, family, educational and cultural conditions) that involves aging (Neri \& Vieira, 2013; Schlösser et al., 2014). To better understand the extent of these factors and the impacts late in life, it is necessary to increase research with older adults, a segment of the population still little studied (American Psychological Association, 2014; United Nations, 2012).

In Brazil, the conditions provided for this population, in relation to healthcare, employ- 
ment opportunities and social inclusion are still very incipient (IBGE, 2010; Neri \& Vieira, 2013). These concerns are reflected in studies that seek to understand the causes and determinants of successful aging (Bastos-Formighieri \& Pasian, 2012). Positive aspects, such as the maturity, wisdom and life experience of older adults, need to be valorized (Baltes \& Baltes, 1990; Garcia-Santos et al., 2012; Neri \& Vieira, 2013). Therefore, it is necessary to optimize personal and social resources to face the aging process, which can result in changes in the motivations to make social contacts of the older adults (Carneiro \& Falcone, 2013; Carneiro et al., 2007; Del Prette \& Del Prette, 2005).

As social skills are related to mental health, greater personal and professional satisfaction, the reduction of stress and increases in the quality of life (Angélico et al., 2012; Braz et al., 2013; Guilland \& Monteiro, 2010; Pinto \& Barham, 2014), they have been studied in all settings: hospital, school, family and work (Braz et al., 2013; Del Prette \& Del Prette, 2013; Di Domenico-Grazziotin \& Scortegagna, 2012, 2013; Feitosa et al., 2012). There are also studies that demonstrate the importance of this construct in the prevention of mental disorders (Del Prette et al., 2013) and more recently, for human aging with quality of life (Braz et al., 2013; Braz et al., 2011; Carneiro \& Falcone, 2013; Carneiro et al., 2007).

Regarding conversation and social confidence (F3), the OAG participants remained slightly below the medium range, while the AG presented values above the medium range. There was a significant negative and low correlation between SS and older age $(r=.259)$. It appears that the more advanced the age, the more conversation and social confidence (F3) skills tend to decline. This trend may be due to the fact that many older adults start to focus on the preservation of the physical and mental aspects, and to reduce social and interpersonal investments (McAdams \& Olson, 2010; O'Brien et al., 2013).

Although the scores indicate a less developed repertoire of conversation and social confidence skills, which depict, for example, the ability to deal with social situations of ap- proximation, asking a favor and refusing abusive requests (Del Prette \& Del Prette, 2005, 2013), it is important to analyze the standard deviations of the OAG $(S D=36.10)$, and of the $\mathrm{AG}$ $(S D=33.99)$, which demonstrate heterogeneity. It can be observed that although the participants in the OAG presented results below the medium range there was a pattern of behavior, with evidence for the potential of this skill among some of the participants. Conversely, while the AG subjects presented results higher than the medium range and demonstrated an elaborate potential, they also showed no homogeneity, as some individuals presented limitations. In comprehending these findings, it is necessary to consider that, in addition to age, other components, such as gender, education and the socio-economic, cultural and occupational status (Del Prette \& Del Prette, 2011; Neri \& Vieira, 2013), as well as personality traits, can influence the behavior (Caballo, 2008; Garcia-Santos et al., 2012).

In F5, which covers the control of anger and aggression against others in aversive situations, there was a negative and moderate correlation with older age $(r=.490)$, indicating that, as the age increases, this skill tends to present less development and to decline. This result indicates the possibility of a deficit in older adults regarding the skill of self-control of aggression faced with aversive situations. Advanced age can lead to more prominent feelings of fear, despair and insecurity, which may contribute to a decrease in self-control. As age advances, the individual begins to realize the future in a restricted way, since there is a time limit for achieving what is wanted, and for life itself (Neri \& Vieira, 2013).

Although the OAG showed lower levels in SS compared to the AG, it is possible to promulgate the potentials and overcome the dystonic aspects of this phase (Braz et al., 2011; Carneiro \& Falcone, 2013; Del Prette \& Del Prette, 2011). They have ability to integrate the past, to be productive in the present and to help new generations (Baltes \& Baltes, 1990; Braz et al., 2013; Garcia-Santos et al., 2012), however, it is necessary for society to provide conditions for this and recognizes their importance (Braz et al., 2011; Carneiro et al., 2007; Neri \& Vieira, 2013). 
Going one step further, advances in the field of psychology are necessary, especially in the study of older adults, and in the development of evaluation measures which can respond to the demands of this population. There is a need to construct psychological evaluation tools, as this population is shown to be different in various contexts, and in terms of SS (Braz et al., 2013; Braz et al., 2011; Carneiro \& Falcone, 2013; Del Prette \& Del Prette, 2013).

As can be seen, the results of this study provide important findings, in that they elucidate characteristics of SS in older adults compared to adults. Among the limitations to consider in achieving the results, it should be highlighted that the study used a cross-sectional and correlational design and, therefore, the statistical analyzes do not allow causal conclusions, only indicating possible associations between variables.

Regarding contributions, it is emphasized that the study sought to investigate positive dimensions of aging, such as SS, which is unusual in the literature, especially with older adults. It was verified that deficits occurred in SS with older age, which highlights the implementation of actions for the health of this population, and the importance of constructing a social skills instrument with specific standards. Finally, considering that other aspects, such as education, socioeconomic status, gender, lifestyle and personality, can influence social skills, and need to be constantly examined, there is a need for further studies with more representative samples, from other regions and from large centers.

\section{References}

American Psychological Association. (2014). Guidelines for psychological practice with older adults. American Psychologist, 69(1), 34-65. doi:10.1037/a0035063

Angélico, A. P., Crippa, J. A. S., \& Loureiro, S. R. (2012). Utilização do Inventário de Habilidades Sociais no diagnóstico do transtorno de ansiedade social. Psicologia: Reflexão e Crítica, 25(3), 467476. doi:10.1590/S0102-7972201200030 0006

Baltes, P., \& Baltes, M. (1990). Psychological perspectives on successful aging: The model of selective optimization with compensation. In P. Baltes \& M. Baltes (Eds.), Successfulaging (pp. 1-34). New York: Cambridge University Press.

Bandeira, M., Costa, M. N., Del Prette, Z. A. P., Del Prette, A., \& Gerk-Carneiro, E. (2000). Qualidades psicométricas do Inventário de Habilidades Sociais (IHS): Estudo sobre a estabilidade temporal e a validade concomitante. Estudos de Psicologia (Natal), 5(2), 401-419. doi:10.1590/ S1413-294X2000000200006

Bastos-Formighieri, M. de S., \& Pasian, S. R. (2012). O Teste de Pfister em idosos. Avaliação Psicológica, 11(3), 435-448.

Braz, A. C., Cômodo, C. N., Del Prette, Z. A. P., Del Prette, A., \& Fontaine, A. M. G. (2013). Habilidades sociales e intergeneracionalidad en las relaciones familiares. Apuntes de Psicología, 31(1), 77-84.

Braz, A. C., Del Prette, Z. A. P., \& Del Prette, A. (2011). Assertive social skills training for the elderly. Behavioral Psychology/Psicología Conductual, 19(2), 373-387.

Caballo, V. E. (2008). Conceitos atuais sobre os transtornos da personalidade. In V. E. Caballo (Ed.), Manual de transtornos de personalidade: Descrição, avaliação e tratamento (pp. 25-56). São Paulo, SP: Santos.

Carneiro, R. S., \& Falcone, E. M. O. (2013). O desenvolvimento das habilidades sociais em idosos e sua relação na satisfação com a vida. Estudos de Psicologia (Natal), 18(3), 517-523. doi:10.1590/ S1413-294X2013000300012

Carneiro, R. S., Falcone, E. M., Clark, C., Del Prette, Z., \& Del Prette, A. (2007). Qualidade de vida, apoio social e depressão em idosos: Relação com habilidades sociais. Psicologia: Reflexão e Crítica, 20(2), 229-237. doi:10.1590/S010279722007000200008

Del Prette, Z. A. P., \& Del Prette, A. (2001). Inventário de Habilidades Sociais (IHS - Del- Prette): Manual de aplicação, apuração e interpretação. São Paulo, SP: Casa do Psicólogo.

Del Prette, Z. A. P., \& Del Prette, A. (2005). Inventário de Habilidades Sociais (IHS Del Prette): Manual de aplicação, apuração e interpretação (3. ed.). São Paulo, SP: Casa do Psicólogo.

Del Prette, Z. A. P., \& Del Prette, A. (2011). Psicologia das habilidades sociais: Terapia, educação e trabalho (8. ed.). Petrópolis, RJ: Vozes. 
Del Prette, Z. A. P., \& Del Prette, A. (2013). Social Skills Inventory (SSI-Del-Prette): Characteristcs and studies in Brazil. In F. Osório (Ed.), Social Anxiety Disorders: From theory to practice (pp. 49-62). New York: New Science.

Del Prette, Z. A. P., Falcone, E. M. O., \& Murta, S. G. (2013). Contribuições do campo das habilidades sociais para compreensão, prevenção e tratamento dos transtornos da personalidade. In L. F. Carvalho \& R. Primi (Eds.), Perspectivas em psicologia dos transtornos da personalidade: Implicações teóricas e práticas (pp. 326-358). São Paulo, SP: Casa do Psicólogo.

Di Domenico-Grazziotin, J. B., \& Scortegagna, S. A. (2012). Zulliger Habilidade Social: Evidências de validade no contexto empresarial. Psicologia: Reflexão e Crítica, 25(1), 69-78. doi:10.1590/ S0102-79722012000100009

Di Domenico-Grazziotin, J. B., \& Scortegagna, S. A. (2013). Relacionamento interpessoal, produtividade e habilidades sociais: Um estudo correlacional. Psico-USF, 18(3), 491-500. doi:10.1590/ S1413-82712013000300015

Feitosa, F. B., Del Prette, Z. A. P., \& Del Prette, A. (2012). Social skills and academic achievement: The mediating function of cognitive competence. Temas em Psicologia, 20(1), 61-70.

Garcia-Santos, S. C., Almeida, L. da S., \& Werlang, B. S. G. (2012). Excelência humana: A contribuição da personalidade. Paidéia (Ribeirão Preto), 22(52), 251-259. doi:10.1590/S0103$-863 X 2012000200011$

Guilland, R., \& Monteiro, J. K. (2010). Jovem em situação de desemprego: Habilidades sociais e bem-estar psicológico. Psicologia: Teoria e Prática, 12(3), 149-163.

Instituto Brasileiro de Geografia e Estatística. (2010). Censo Demográfico de 2010. Retrieved from http://www.ibge.gov.br/home/presidencia/noticias/noticia_visualiza.php?id noticia $=1866 \&$ id_pagina $=1$
McAdams, D. P., \& Olson, B. D. (2010). Personality development: Continuity and change over the life course. Annual Review of Psychology, 61, 517542. doi:10.1146/annurev.psych.093008.100507

Neri, A. L., \& Vieira, L. A. M. (2013). Envolvimento social e suporte social percebido na velhice. Revista Brasileira de Geriatria e Gerontologia, 16(3), 419-432. doi:10.1590/S180998232013000300002

O’Brien, E. D., Konrath, S. H., Gruhn, D., \& Hagen, A. L. (2013). Empathic concern and perspective taking: Linear and quadratic effects of age across the adult life span. The Journals of Gerontology, Series B: Psychological Sciences and Social Sciences, 68(2), 168-175. doi:10.1093/geronb/ gbs055

Pinto, F. N. F. R., \& Barham, E. J. (2014). Habilidades sociais e estratégias de enfrentamento de estresse: Relação com indicadores de bemestar psicológico em cuidadores de idosos de alta dependência. Revista Brasileira de Geriatria e Gerontologia, 15(3), 635-655. doi:10.1590/1809-9823.2014.13043

Schlösser, A., Rosa, G. F. C., \& More, C. L. O. O. (2014). Revisão: Comportamento suicida ao longo do ciclo vital. Temas em Psicologia, 22(1), 133-145. doi:10.9788/TP2014.1-11

United Nations. (2012). World population prospects: The 2010 revision. Retrieved from http://esa. un.org/wpp/P-WPP/htm/PWPP_PopulationAge65 Plus. ht
Recebido: $14 / 10 / 2014$

$1^{a}$ revisão: 08/04/2015 Aceite final: 22/05/2015 